\title{
INCOME INEQUALITY IN POLAND AND THE UNITED KINGDOM. DECOMPOSITION OF THE THEIL INDEX*
}

\author{
Joanna Muszyńska, Ph.D. ${ }^{1}$ \\ Jarosław Oczki, Ph.D. ${ }^{2}$ \\ Ewa Wędrowska, Ph.D., Associate Professor ${ }^{3}$ \\ Nicolaus Copernicus University \\ Faculty of Economic Sciences and Management \\ Gagarina 13a, 87-100 Toruń, Poland \\ ${ }^{1}$ e-mail: Joanna.Muszynska@umk.pl \\ ${ }^{2}$ e-mail: Jaroslaw.Oczki@umk.pl \\ ${ }^{3}$ e-mail: Ewa.Wedrowska@umk.pl
}

Received 20 September 2017, Accepted 27 March 2018

\begin{abstract}
The aim of the article is to compare inequalities of the household disposable income in Poland and the UK. We analyse the Theil index for types of households in 2005 and 2014. We also aim at finding out how household types contribute to the level of overall income inequality in the UK and Poland. We calculate and decompose the Theil indices based on the equivalised disposable household income from the European Union Statistics on Income and Living Conditions (EU-SILC) database. We find that "two adults below 65 with no dependent children" household group is the main contributor to the overall Theil index in both countries. We also conclude that the between-group component of the Theil index decreases in Poland and increases in the UK and, in effect, in 2014, it is twice as high in the UK as in Poland.
\end{abstract}

Keywords: household income, income inequality, Theil index, decomposition, EU-SILC

JEL classification: C10, D14, D63

\footnotetext{
* This paper is prepared within the research project: Income Inequalities in the European Union Countries (Eurostat, No.: 164/2016-EU-SILC) and is based on data from Eurostat, EU Statistics on Income and Living Conditions - EU-SILC CROSS-SECTIONAL UDB 2015 - version 2 of March 2017. The responsibility for all conclusions drawn from the data lies entirely with the authors.
} 


\section{Introduction}

The past decades has seen an increase in income inequality, especially in highly developed countries (ILO, 2015; OECD, 2015), and the issue of growing inequalities, its causes and consequences, has attracted the attention of economists and policy makers. A range of indices is used in describing inequality. The most popular measures of income inequality are: the Gini index, the measures belonging to the Generalised Entropy class of coefficients, e.g. Theil and Atkinson indices, and the percentile ratios. One way of analyzing inequality is through decomposition of income inequality measures. The decomposition may shed light on what factors and processes determine income inequality, and what is their contribution to overall inequality (Jansen, Dessens, Verhoeven, 2013). Early publications in the field provide empirical results on income inequality decomposition by population subgroups and by income sources (Bourguignon, 1979; Shorrocks, 1980, 1982, 1984). Other authors investigate regional decomposition of income inequality (Kim, Jeong, 2003). A number of studies presented the results of decomposition of Gini index, and discussed the methodological aspects of the procedure (Rani, Furrer, 2016; Larraz, 2015). Special attention in the research concerning decomposition of income inequality was paid to the indices which could be additively decomposed, among them - the Theil index (Rohde, 2008; Frosini, 2012).

The aim of the article is to compare income inequalities in Polish and British household groups between 2005 and 2014, with the use of the Theil index. We also aim at finding out how household types contribute to the level of overall income inequality in UK and Poland.

\section{Data}

Our data come from the European Union Statistics on Income and Living Conditions (EU-SILC). We use micro data on two types of income: equivalised disposable household income before social transfers except old-age and survivors' benefits, and equivalised disposable household income after social transfers. The former is calculated as the total disposable income minus unemployment, sickness, and disability benefits, education and family/children related allowances, social exclusion and housing allowances, plus old age benefits and survivor benefits. The latter includes all the above benefits and allowances. The average income and inequality measures are estimated with the use of personal cross-sectional weights. The income data for the UK are taken from the 2005 and 2014 EU-SILC survey, and for Poland, the data come from 
2006 and 2015 survey. ${ }^{1}$ The British sample contained 10,826 households (25,505 individuals) in 2005, and 9,860 households (22,476 individuals) in 2014, while the Polish sample included 14,914 households $(45,122$ individuals) in 2006, and 12,183 households (33,652 individuals) in 2015.

We follow the classification for the household type used in EU-SILC dataset:

H-5 - a one-person household,

H-6 - two adults, both under 65 , with no dependent children,

H-7 - two adults, at least one 65 years or more, with no dependent children,

H-8 - other households without dependent children,

H-9 - a single parent with one or more dependent children,

H-10 - two adults with one dependent child,

H-11 - two adults with two dependent children,

H-12 - two adults with three or more dependent children,

H-13 - other households with dependent children,

H-16 - other households.

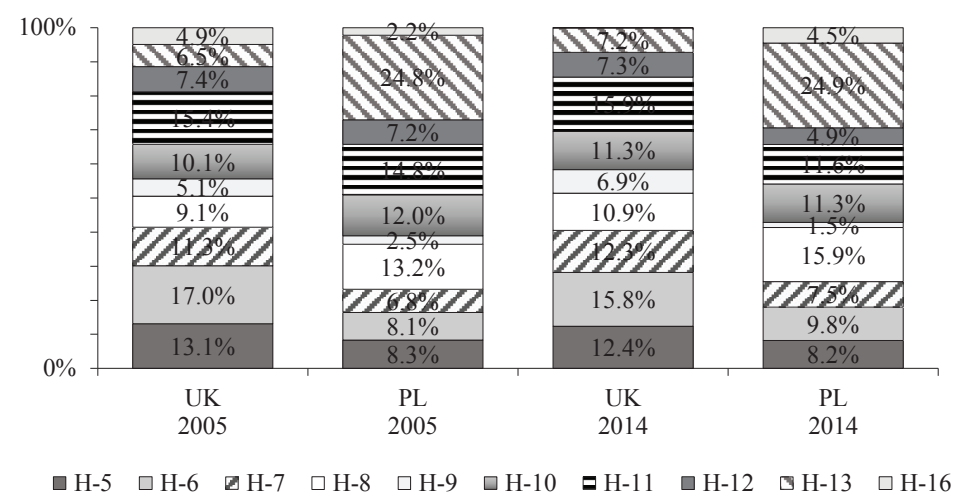

Figure 1. The composition of Polish and British households by types in 2005 and 2014 Source: authors' own elaboration.

Figure 1 presents the composition of British and Polish households. The Polish household structure is characterized by a much smaller share of the households consisting of two adults, both under 65, with no dependent children (H-6). In 2014, almost one fifth of British households belonged to this group, while in Poland, it was less than $10 \%$. As much as $25 \%$ of Polish

\footnotetext{
1 The EU-SILC income reference period is a previous year for all countries except the United Kingdom for which the income reference period is the current year (http://ec.europa.eu/eurostat).
} 
households belong to a group "other households with dependent children" (H-13), as opposed to only $7.3 \%$ in the UK. H-13 group in its vast part is composed of multigenerational families. These households are much more prevalent in Poland as compared with the UK, because a relatively low standard of living and housing shortages force many Polish families to share dwelling with their relatives. Single parent households are more common in the UK $(6.9 \%$ of all households) than in Poland, where they account for as little as $1.5 \%$ of all households. In 2005, in the UK, there were $50.5 \%$ of households with no dependent children, and, in 2014 , there were $51.4 \%$, while in Poland $36.4 \%$ of households had no dependent children in 2005, and, in 2014, the percentage was $41.4 \%$. In both countries, the structures with regard to household types have not changed much between 2005 and 2014. The most noticeable changes are: the increase of share of single parent households in the UK from $5.1 \%$ to $6.9 \%$, and decreases in share of large families and families with two children in Poland.

\section{Methodology}

The Theil index is one of the inequality measures that belongs to the entropy measures from information theory, and was developed by Theil (1967). The use of inequality measures based on entropy can be related to the use of a descriptive approach to measure inequality.

The Generalised Entropy (GE) class of inequality indices (Cowell, 1977) is given by:

$$
G E(\alpha)=\frac{1}{n\left(\alpha^{2}-\alpha\right)} \sum_{i=1}^{n}\left[\left(\frac{y_{i}}{\bar{y}}\right)^{\alpha}-1\right], \alpha \neq 0, \alpha \neq 1
$$

where $y_{i}$ is the equivalised disposable income of an individual $i, \bar{y}$ is the population mean income, and $n$ is the number of individuals in the population. ${ }^{2}$

Parameter $\alpha \in R \backslash\{0,1\}$ describes the sensitivity of $G E(\alpha)$ to income dissimilarity in different parts of income distribution. The higher the positive value of $\alpha$, the more sensitive $G E(\alpha)$ is to the income differences at the top of the distribution. The lower the negative value of $\alpha$, the more sensitive $G E(\alpha)$ is to the income differences at the bottom of the distribution. In empirical work, the range of values for $\alpha$ is typically restricted to $[-1,2]$ because, otherwise, the estimates may be too much influenced by the limited number of very small incomes or very high incomes (Jenkins, 2009).

Cowell (2006) shows that any inequality measure that satisfies a particular axiomatic framework may belong to a class of the Generalised Entropy.

\footnotetext{
2 The Generalized Entropy family is also discussed in Cowell, Kuga (1981).
} 
Two particular cases of $G E$ are used to measure inequalities: $\alpha=0$ and $\alpha=1$.

For $\alpha=0$, expression (1) becomes:

$$
G E(0)=\lim _{\alpha \rightarrow 0} G E(\alpha)=-\frac{1}{n} \sum_{i=1}^{n} \ln \left(\frac{y_{i}}{\bar{y}}\right)
$$

$\mathrm{GE}(0)$ index is called the mean logarithmic deviation (MLD).

For $\alpha=1$, expression (1) becomes:

$$
G E(1)=\lim _{\alpha \rightarrow 1} G E(\alpha)=\frac{1}{n} \sum_{i=1}^{n} \frac{y_{i}}{\bar{y}} \ln \left(\frac{y_{i}}{\bar{y}}\right)=T
$$

Expression (3) describes the Theil index. Expression (1) is not defined for $\alpha=0$ and $\alpha=1$ so expressions (2) and (3) are calculated by using a rule by de l'Hôpital.

Looking at the Theil index formula above, it is clear that the structure of the formula is that of a weighted sum of direct inequality measures. An important property of the Theil measure and of the class of Generalised Entropy inequality measures is the additive decomposability, which implies that the aggregate inequality measure can be decomposed into inequality within and between any arbitrarily defined population subgroups (Rohde, 2008).

The origin of the contemporary inequality decomposition literature can be found in Shorrocks $(1980,1982,1984)$. Shorrocks analysed decomposition of inequality by income sources, by the type of household (e.g. single persons, married couples, families with children), or by subgroups which share common characteristics such as age, household size, region, household members' occupation, or education. Many of the inequality measures can be decomposed into components reflecting only the size, mean and inequality value of each population subgroup, or the income source (Heshmati, 2004).

Suppose that a population of all households is grouped into mutually exclusive and collectively exhaustive $h$ socioeconomic subgroups (different household type groups), and the Theil index of each subgroup is $T_{g}$. The overall inequality of the population measured by the Theil index (3) can be decomposed as follows:

$$
T=\sum_{g=1}^{h} s_{g} T_{g}+\sum_{g=1}^{h} s_{g}\left(\ln \left(\frac{s_{g}}{p_{g}}\right)\right)=T_{w}+T_{b}
$$

where $s_{g}=\frac{\sum_{j=1}^{n_{g}} y_{j}}{\sum_{i=1}^{n} y_{i}}$ is group $g$ 's income share of the total income, and $p_{g}=\frac{n_{g}}{n}$ is group $g$ 's population share of the total population $\left(n_{g}\right.$ is the number of individuals in group $g$ ). The total 
inequality $T$ can be expressed as a sum of a within-group inequality term and between-group term. The first sum in expression (4) is within-group component $\left(T_{w}\right)$ of the Theil index $T$. $T_{w}$ is the average of the Theil indices of $h$ subgroups weighted by income shares, and describes a part of overall inequality that is due to inequality within subgroups. The second $\operatorname{sum}\left(T_{b}\right)$ is the between-group component of the Theil index and measures the extent of inequality due to the differences in the group mean income. $T_{b}$ is the component of overall inequality that is due to the between-group inequality. In fact, $T_{b}$ is the entropy index (Theil, 1967), which is interpreted as a difference index, and can be used to evaluate discrepancies between two distributions (income and population). It is a non-symmetric measure of the dissimilarity between the two distributions.

The empirical analysis in the paper is based on the EU-SILC household micro-data set, thus we modified the formula (3) describing the Theil index:

$$
T=\frac{1}{\sum_{i=1}^{N} w_{i}} \sum_{i=1}^{N} w_{i} \frac{y_{i}}{\bar{y}} \ln \left(\frac{y_{i}}{\bar{y}}\right)
$$

where the weight variable $\left(w_{i}\right)$ is the personal cross-sectional weight.

\section{Empirical results}

In the first step of our analysis, we investigate the structure of total household incomes by household groups in the UK and Poland in 2005 and 2014. The composition of the total income corresponds to the structure of households by types in both countries - H-6 has the largest share of the total household income in the UK, and H-13 type households have the largest percentage of the income of all Polish households. A comparison of income shares by household groups before and after social transfers facilitates the analysis of redistributive function of welfare systems in the UK and Poland. In the UK, substantial income gains can be observed in single parent households - the share of total income received by this household group in 2014 almost doubles when social transfers are accounted for. In Poland, the difference between respective share coefficients is small, which indicates a relatively poor level of state subsidies to the incomes of single parents.

Other household groups which increase their share in total income through social transfers are: large families (H-12), especially in Poland in 2005, one-person households (only in 2014, since, due to the ageing of the populations, a higher share of one-person households received 
old-age social transfers than in 2005), and other households with dependent children in Poland - an increase of the share of total income in 2014 from 20.2 to $24.7 \%$.

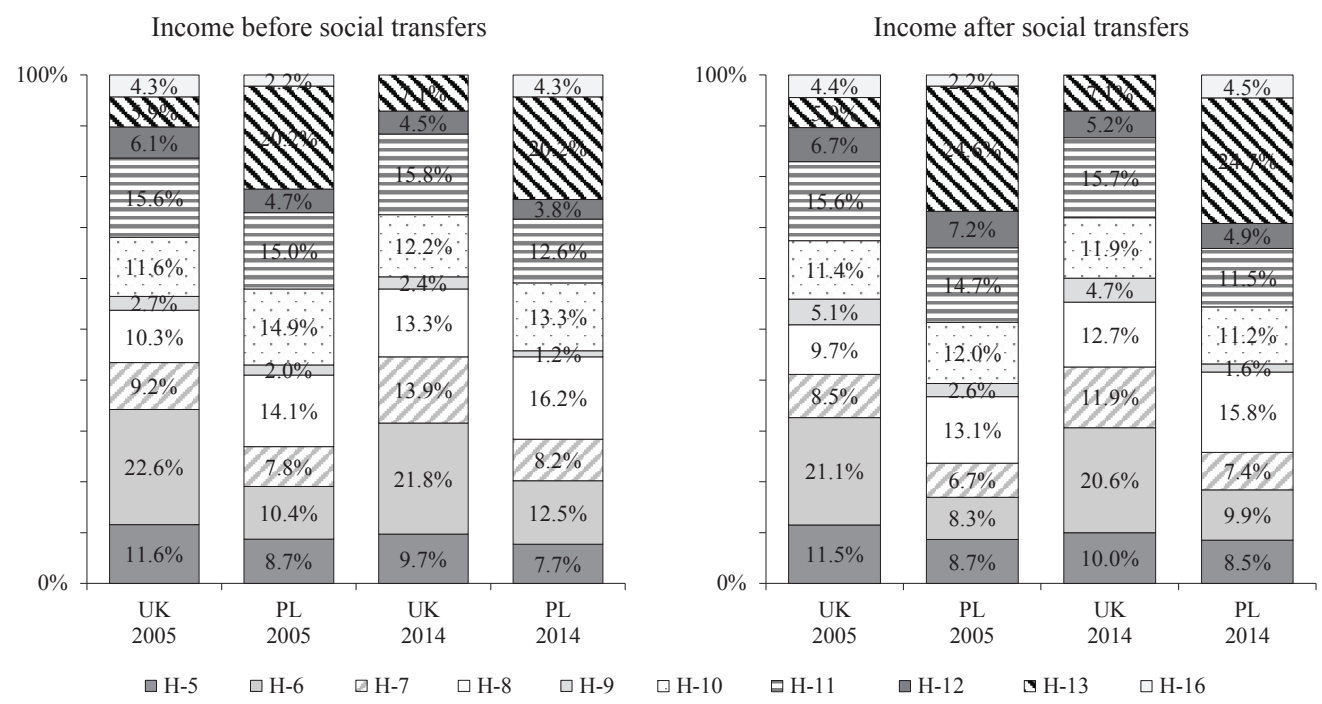

Figure 2. The composition of the total household income by household types in the UK and Poland in 2005 and 2014

Source: authors' own elaboration.

In 2005, in the UK, the highest Theil index for the income before social transfers is observed in "2 adults with three or more dependent children" and "single parent with one or more dependent children" household groups (Table 1). These two household types were also characterized by one of the smallest average incomes. In Poland, the greatest inequality is observed among a single-parent household group -0.363 , and in " 2 adults with no dependent children, both adults under 65 years" group -0.286 . The smallest income inequality in the UK is observed in "other households with dependent children" - 0.179 , while in Poland, in a household group of two adults with no dependent children where at least one adult is 65 years old and older -0.140 . The decomposition of the total Theil index indicates that $8.3 \%$ and $7.1 \%$ of the total income inequality in the UK and Poland, respectively, can be ascribed to the betweengroup dispersion. In both countries, two-adult households below 65 with one or no dependent children experienced the largest average relative income. The poorest households in the UK were definitely those of single parents, with only a half of the average equivalised disposable household income level of the total population, while in Poland, they were large families (two adults with three or more dependent children) - with approx. 2/3 of the national average. 
As we expected, the Theil indices based on the incomes after social transfers are on average smaller than those calculated for the incomes before social transfers: 0.223 as compared to 0.268 in the UK, and 0.190 as compared to 0.243 in Poland. In the UK, the largest difference in the Theil values with regard to social transfers is observed in a single-parent household group. The Theil index for the incomes after social transfers for this group is second lowest out of all the household types, while for the incomes before social transfers, it is second largest. Also, a relative level of the income of single-parent households improved from $51.5 \%$ to $65.3 \%$ of the total average. In Poland, on the other hand, the income inequality in single-parent households is highest also for the incomes after social transfers. The difference between relative incomes before and after social transfers in this group is relatively small. A comparison of the Theil indices for the incomes before and after social transfers leads to the conclusion that the British social security system significantly reduces the income inequality in single-parent households, and it is not very effective in diminishing inequality in large family households - the Theil index for this group for the income after social transfers remains high at 0.327 .

Table 1. Decomposition of the Theil indices for equivalised disposable household incomes before social transfers in 2005

\begin{tabular}{|c|c|c|c|c|c|c|}
\hline \multirow[t]{2}{*}{ Household type } & $\begin{array}{l}\text { Relation of the } \\
\text { average income } \\
\text { in group } g \text { to the } \\
\text { average income } \\
(\%)\end{array}$ & Theil T & $\begin{array}{l}\text { Contribution of } \\
\text { group } g \text { to the } \\
\text { overall Theil } \\
\text { value } \\
(\%)\end{array}$ & $\begin{array}{l}\text { Relation of the } \\
\text { average income } \\
\text { in group } g \text { to the } \\
\text { average income } \\
(\%)\end{array}$ & Theil T & $\begin{array}{l}\text { Contribution of } \\
\text { group } g \text { to the } \\
\text { overall Theil } \\
\text { value } \\
(\%)\end{array}$ \\
\hline & \multicolumn{3}{|c|}{ UK } & \multicolumn{3}{|c|}{ PL } \\
\hline H-5 & 89.0 & 0.243 & 10.5 & 104.2 & 0.214 & 7.6 \\
\hline H-6 & 133.2 & 0.234 & 19.7 & 127.9 & 0.286 & 12.2 \\
\hline H-7 & 81.0 & 0.234 & 8.0 & 115.2 & 0.140 & 4.5 \\
\hline H-8 & 112.6 & 0.228 & 8.7 & 106.7 & 0.191 & 11.0 \\
\hline H-9 & 51.5 & 0.366 & 3.6 & 79.7 & 0.363 & 3.0 \\
\hline $\mathrm{H}-10$ & 114.5 & 0.226 & 9.8 & 124.2 & 0.238 & 14.6 \\
\hline $\mathrm{H}-11$ & 101.3 & 0.238 & 13.8 & 101.3 & 0.253 & 15.6 \\
\hline $\mathrm{H}-12$ & 83.1 & 0.439 & 10.0 & 65.4 & 0.254 & 4.9 \\
\hline H-13 & 90.7 & 0.179 & 4.0 & 81.5 & 0.207 & 17.2 \\
\hline $\mathrm{H}-16$ & 89.1 & 0.215 & 3.5 & 99.9 & 0.246 & 2.3 \\
\hline Total & 100.0 & 0.268 & - & 100.0 & 0.243 & - \\
\hline $\begin{array}{l}\text { Within-group } \\
\text { component }\left(\mathrm{T}_{\mathrm{W}}\right)\end{array}$ & \multicolumn{3}{|c|}{0.246} & \multicolumn{3}{|c|}{0.226} \\
\hline$\%$ Contribution & \multicolumn{3}{|c|}{91.7} & \multicolumn{3}{|c|}{92.9} \\
\hline $\begin{array}{l}\text { Between-group } \\
\text { component }\left(\mathrm{T}_{\mathrm{b}}\right)\end{array}$ & \multicolumn{3}{|c|}{0.022} & \multicolumn{3}{|c|}{0.017} \\
\hline$\%$ Contribution & \multicolumn{3}{|c|}{8.3} & \multicolumn{3}{|c|}{7.1} \\
\hline
\end{tabular}

Source: authors' own calculations. 
Table 2. Decomposition of the Theil indices for equivalised disposable household incomes after social transfers in 2005

\begin{tabular}{|c|c|c|c|c|c|c|}
\hline \multirow[t]{2}{*}{ Household type } & $\begin{array}{l}\text { Relation of the } \\
\text { average income } \\
\text { in group } g \text { to the } \\
\text { average income } \\
(\%)\end{array}$ & Theil T & $\begin{array}{l}\text { Contribution of } \\
\text { group } g \text { to the } \\
\text { overall Theil } \\
\text { value } \\
(\%)\end{array}$ & $\begin{array}{l}\text { Relation of the } \\
\text { average income } \\
\text { in group } g \text { to the } \\
\text { average income } \\
(\%)\end{array}$ & Theil T & $\begin{array}{l}\text { Contribution of } \\
\text { group } g \text { to the } \\
\text { overall Theil } \\
\text { value } \\
(\%)\end{array}$ \\
\hline & \multicolumn{3}{|c|}{ UK } & \multicolumn{3}{|c|}{ PL } \\
\hline H-5 & 86.6 & 0.213 & 11.0 & 96.8 & 0.199 & 8.8 \\
\hline H-6 & 128.9 & 0.218 & 20.6 & 127.7 & 0.215 & 11.9 \\
\hline $\mathrm{H}-7$ & 80.9 & 0.216 & 8.2 & 110.9 & 0.125 & 4.8 \\
\hline $\mathrm{H}-8$ & 114.1 & 0.191 & 8.3 & 109.6 & 0.141 & 10.6 \\
\hline H-9 & 65.3 & 0.143 & 3.2 & 83.0 & 0.228 & 2.6 \\
\hline $\mathrm{H}-10$ & 115.8 & 0.194 & 9.9 & 121.1 & 0.199 & 15.2 \\
\hline $\mathrm{H}-11$ & 104.4 & 0.196 & 13.7 & 100.3 & 0.205 & 15.8 \\
\hline $\mathrm{H}-12$ & 87.3 & 0.327 & 9.8 & 68.5 & 0.175 & 4.5 \\
\hline $\mathrm{H}-13$ & 95.7 & 0.134 & 3.6 & 84.4 & 0.147 & 16.0 \\
\hline $\mathrm{H}-16$ & 90.7 & 0.177 & 3.5 & 99.6 & 0.200 & 2.3 \\
\hline Total & 100.0 & 0.223 & - & 100.0 & 0.190 & - \\
\hline $\begin{array}{l}\text { Within-group } \\
\text { component }\left(T_{w}\right)\end{array}$ & \multicolumn{3}{|c|}{0.205271} & \multicolumn{3}{|c|}{0.176396} \\
\hline$\%$ Contribution & \multicolumn{3}{|c|}{91.9} & \multicolumn{3}{|c|}{92.6} \\
\hline $\begin{array}{l}\text { Between-group } \\
\text { component }\left(T_{b}\right)\end{array}$ & \multicolumn{3}{|c|}{0.017959} & \multicolumn{3}{|c|}{0.014024} \\
\hline$\%$ Contribution & \multicolumn{3}{|c|}{8.1} & \multicolumn{3}{|c|}{7.4} \\
\hline
\end{tabular}

Source: authors' own calculations.

Table 1 and 2 also present the values of the contributions of particular household groups to the overall Theil index in 2005. The percentage value of the coefficient for a particular household group depends on two factors: the share of income received by that household group in the total income of all households, and the inequality of income in this group measured by the Theil index. In the UK, "two adults, both under 65, with no dependent children" group contributed most to the total income inequality. It is a result of the high, $17 \%$, share of these households in all the households in the sample. In Poland, three types of households account for almost half of the overall inequality of incomes, both, before and after social transfers: H-10, H-11, and H-13 (two adults with one and two dependent children, and other households with dependent children).

Between 2005 and 2014, the Theil index describing the income inequality of incomes before social transfers in the total population decreased in both countries - in Poland from 0.243 to 0.189 , and in the UK from 0.268 to 0.218 (Tables 1 and 3). The decrease is observed in almost every household group. For example, in Poland, the Theil index in a single-parent group dropped from 0.363 to 0.269 . There are only three groups where inequalities increased in 
2005-2014: in the UK the value of the Theil index of single-parent households reached 0.473 (a considerable increase from 0.366 in 2005), in "other households with dependent children" group it increased from 0.179 to 0.223 , and, in Poland, a rise of the index in a large-family household group is observed (from 0.254 to 0.294 ).

Table 3. Decomposition of the Theil indices for equivalised disposable household incomes before social transfers in 2014

\begin{tabular}{|c|c|c|c|c|c|c|}
\hline \multirow[t]{2}{*}{ Household type } & $\begin{array}{l}\text { Relation of the } \\
\text { average income } \\
\text { in group } g \text { to the } \\
\text { average income } \\
(\%)\end{array}$ & $\begin{array}{l}\text { Theil } \\
\mathrm{T}\end{array}$ & $\begin{array}{l}\text { Contribution of } \\
\text { group } g \text { to the } \\
\text { overall Theil } \\
\text { value } \\
(\%)\end{array}$ & $\begin{array}{l}\text { Relation of the } \\
\text { average income } \\
\text { in group } g \text { to the } \\
\text { average income } \\
(\%)\end{array}$ & Theil T & $\begin{array}{l}\text { Contribution of } \\
\text { group } g \text { to the } \\
\text { overall Theil } \\
\text { value } \\
(\%)\end{array}$ \\
\hline & \multicolumn{3}{|c|}{ UK } & \multicolumn{3}{|c|}{ PL } \\
\hline $\mathrm{H}-5$ & 82.9 & 0.196 & 8.7 & 94.3 & 0.186 & 7.5 \\
\hline H-6 & 134.8 & 0.193 & 19.4 & 127.8 & 0.257 & 16.9 \\
\hline $\mathrm{H}-7$ & 98.6 & 0.158 & 9.5 & 109.0 & 0.127 & 5.5 \\
\hline $\mathrm{H}-8$ & 115.9 & 0.142 & 8.7 & 102.3 & 0.142 & 12.1 \\
\hline H-9 & 46.6 & 0.473 & 5.1 & 77.8 & 0.269 & 1.7 \\
\hline H-10 & 105.7 & 0.180 & 10.1 & 117.7 & 0.168 & 11.8 \\
\hline $\mathrm{H}-11$ & 96.9 & 0.179 & 12.9 & 108.8 & 0.207 & 13.8 \\
\hline $\mathrm{H}-12$ & 66.2 & 0.307 & 6.4 & 77.9 & 0.294 & 6.0 \\
\hline $\mathrm{H}-13$ & 94.7 & 0.223 & 7.3 & 81.2 & 0.134 & 14.3 \\
\hline $\mathrm{H}-16$ & 68.5 & 0.129 & 0.0 & 95.2 & 0.171 & 3.9 \\
\hline Total & 100.0 & 0.218 & - & 100.0 & 0.189 & - \\
\hline $\begin{array}{l}\text { Within-group } \\
\text { component }\left(\mathrm{T}_{\mathrm{w}}\right)\end{array}$ & \multicolumn{3}{|c|}{0.192} & \multicolumn{3}{|c|}{0.177} \\
\hline$\%$ Contribution & \multicolumn{3}{|c|}{88.1} & \multicolumn{3}{|c|}{93.4} \\
\hline $\begin{array}{l}\text { Between-group } \\
\text { component }\left(\mathrm{T}_{\mathrm{b}}\right)\end{array}$ & \multicolumn{3}{|c|}{0.026} & \multicolumn{3}{|c|}{0.012} \\
\hline$\%$ Contribution & \multicolumn{3}{|c|}{11.9} & \multicolumn{3}{|c|}{6.6} \\
\hline
\end{tabular}

Source: authors' own calculations.

In both countries, in 2014, similarly to year 2005, household members in the group "two adults under 65 with no dependent children" receive the highest income. On the other hand, the low income before social transfers of British single-parent households deteriorated even further - in 2014, the relative income of an average member of this group is less than half (46.6\%) of the country-wide average. However, the largest drop in the relative income is observed in "two adults with three or more dependent children" group - from 83.1 to $66.2 \%$. In Poland, the relative income of large-family households with two adults improved, while that of singleparent households did not change significantly. 
Table 4. Decomposition of the Theil indices for equivalised disposable household incomes after social transfers in 2014

\begin{tabular}{|c|c|c|c|c|c|c|}
\hline \multirow[t]{2}{*}{ Household type } & $\begin{array}{l}\text { Relation of the } \\
\text { average income } \\
\text { in group g to the } \\
\text { average income } \\
(\%)\end{array}$ & Theil T & $\begin{array}{l}\text { Contribution of } \\
\text { group g to the } \\
\text { overall Theil } \\
\text { value } \\
(\%)\end{array}$ & $\begin{array}{l}\text { Relation of the } \\
\text { average income } \\
\text { in group } g \text { to the } \\
\text { average income } \\
(\%)\end{array}$ & Theil T & $\begin{array}{l}\text { Contribution of } \\
\text { group g to the } \\
\text { overall Theil } \\
\text { value } \\
(\%)\end{array}$ \\
\hline & \multicolumn{3}{|c|}{ UK } & \multicolumn{3}{|c|}{ PL } \\
\hline $\mathrm{H}-5$ & 81.2 & 0.160 & 9.1 & 89.0 & 0.184 & 8.6 \\
\hline H-6 & 130.7 & 0.198 & 23.1 & 126.4 & 0.224 & 17.2 \\
\hline $\mathrm{H}-7$ & 96.7 & 0.146 & 9.9 & 106.4 & 0.116 & 5.6 \\
\hline $\mathrm{H}-8$ & 116.0 & 0.152 & 10.9 & 103.8 & 0.118 & 11.9 \\
\hline $\mathrm{H}-9$ & 67.7 & 0.127 & 3.4 & 79.5 & 0.204 & 1.6 \\
\hline $\mathrm{H}-10$ & 106.0 & 0.148 & 10.0 & 117.3 & 0.147 & 11.8 \\
\hline $\mathrm{H}-11$ & 98.8 & 0.136 & 12.1 & 107.5 & 0.185 & 14.0 \\
\hline $\mathrm{H}-12$ & 72.3 & 0.176 & 5.2 & 82.5 & 0.218 & 5.4 \\
\hline $\mathrm{H}-13$ & 99.0 & 0.151 & 6.1 & 83.3 & 0.106 & 13.3 \\
\hline $\mathrm{H}-16$ & 75.3 & 0.066 & 0.0 & 94.3 & 0.151 & 3.9 \\
\hline Total & 100.0 & 0.177 & - & 100.0 & 0.163 & - \\
\hline $\begin{array}{l}\text { Within-group } \\
\text { component }\left(\mathrm{T}_{\mathrm{w}}\right)\end{array}$ & \multicolumn{3}{|c|}{0.159} & \multicolumn{3}{|c|}{0.152} \\
\hline$\%$ Contribution & \multicolumn{3}{|c|}{89.9} & \multicolumn{3}{|c|}{93.4} \\
\hline $\begin{array}{l}\text { Between-group } \\
\text { component }\left(\mathrm{T}_{\mathrm{b}}\right)\end{array}$ & \multicolumn{3}{|c|}{0.018} & \multicolumn{3}{|c|}{0.011} \\
\hline$\%$ Contribution & \multicolumn{3}{|c|}{10.1} & \multicolumn{3}{|c|}{6.6} \\
\hline
\end{tabular}

Source: authors' own calculations.

Continuing the analysis of the incomes before social transfers, in the UK as well as in Poland, the H-6 group (two adults below 65 with no dependent children) remained the main contributor to the overall Theil index in 2014. The significant influence of this group on the total inequality is due to the high share of this household group in the total income and the relatively high Theil indices in this household group (in both countries the highest value out of all household groups). In the UK, between 2005 and 2014, a drop in the contribution of large family households (H-12), and the increase of other households with dependent children (H-13) are noted. The decrease of the contribution of large families is caused mainly by a sharp drop in the Theil index in this group of households - from 0.439 to 0.307 , but the share of H-12 income in the total income also decreased between 2005 and 2014 from 6.1 to $4.5 \%$ (Figure 1). In Poland, a considerable increase in the contribution of households composed of two adults, both under 65 , with no dependent children (H-6) is observed. It is caused merely by the higher share of the households of this type in the sample (as the Theil index in this group has dropped from 0.286 to 0.257 ). 
Considering the income after social transfers, the Theil indices in both countries in 2014 were smaller than they were in 2005 in the total population as well as in almost all the household groups. In the UK, the index in the total population decreased from 0.223 to 0.176 , and, in Poland, from 0.190 to 0.163 . Only in two household groups in Poland, a rise in inequality is observed: the households composed of two adults younger than 65 with no dependent children, and the households with three and more dependent children.

As it was observed in 2005, in 2014, the Theil indices based on the incomes after social transfers are on average smaller than those calculated for the incomes before social transfers: by $18.8 \%$ in the UK, and by $13.7 \%$ in Poland. In the UK, the largest difference in inequalities with regard to social transfers is observed in a single-parent household group - a drop of the Theil index value from 0.473 to 0.127 . In Poland, the largest decrease in the inequality induced by social policy is observed in single-parent and large-family household groups. The comparison of the Theil indices for the incomes before and after social transfers in 2005 and 2014 leads to the conclusion that the social security system in the UK improved significantly its effectiveness in reducing the income inequality in the households "two adults with three or more dependent children". In Poland, changes in social policy between 2005 and 2014 contributed to the decrease of inequalities of the income after social transfers in a single-parent household group, which, in 2005, noted the highest inequality of income after social transfers. On the other hand, the effectiveness of the Polish social policy towards large families deteriorated - in 2005 social transfers reduced $31.1 \%$ of the income inequality in this group (as measured by the Theil index), while, in 2014 , the reduction was by $25.9 \%$, resulting in the Theil index for the income after social transfers in this household category at the second highest level out of all the household groups in 2014 .

More than $23 \%$ of the overall income inequality in the UK in 2014 can be attributed to the inequality in H-6 household group. In Poland, it is also households of two adults below 65 with no dependent children which contribute most to the total Theil index. Between 2005 and 2014, the contribution coefficients for most household groups in both countries did not change much. The most significant changes are: the decrease in H-12 influence on inequality in the UK (similarly to the trend in the inequality of income before social transfers), and the increase of H-6 contribution and the decrease of H-10 contribution in Poland.

The decomposition of the Theil indices for the UK and Poland also indicates that for both definitions of income: before and after social transfers, the contribution of the between-group components of the coefficient are lower in Poland (they are below 10\% in 2005 and 2014) than in the UK. In the analysed period, in Poland, the between-group components decreased slightly, 
while ,in the UK, they increased from $8.3 \%$ and $8.1 \%$ to $11.9 \%$ and $10.1 \%$ for the incomes before and after social transfers, respectively. As a result, in 2014, they were almost twice as high in the UK as in Poland when the income before social transfers is concerned.

\section{Conclusions}

In 2005 and 2014, in the UK and in Poland, the highest Theil index for the income before social transfers is observed in single-parent households and families with three or more dependent children. In the case of inequality of the income after social transfers, the picture has been mixed - in 2005, large families in the UK were characterized by the highest income inequality, while, in 2014, it was households of two adults under 65 with no dependent children. In Poland, inequalities were highest in single-parent households in 2005, while, in 2014, they were largest in the households with no dependent children and in large families. In both countries, during the analysed period, inequality of the income before and after social transfers decreased in almost all the household groups. Also, the inclusion of social transfers in household incomes leads to the reduction of the total income inequality - in the UK, by $16.8 \%$ in 2005 and by $18.8 \%$ in 2014, while in Poland, by $21.8 \%$ in 2005 and by 13.7\% in 2014. British social policy in 2014 manages to keep income inequalities in all the household groups at relatively low levels (all the Theil indices are below 0.2 ). These results were obtained mostly through a substantial change in the social policy effectiveness in reducing income inequality among large families between 2005 and 2014. Polish social policy in 2014 allows for higher income inequalities, especially in the three groups where the Theil indices exceeded 0.2: two adults, both under 65, with no dependent children; single-parent; and large-families households. In particular, the large-family households have lost much of the social protection which they enjoyed in 2005. In order to achieve better effectiveness of social policy in reduction of income inequality, Polish policy makers should improve the targeting of social protection programmes, especially in a singleparent household group and large families.

Decomposition of the Theil index led us to the conclusion that in the UK and Poland in 2014, and in the UK in 2005, the H-6 group (two adults below 65 with no dependent children) is the main contributor to the overall Theil index. This is due to the high share of this household group in the total income. The only exception is Poland in 2005 where "other households with dependent children" contribute most to the total inequality. Decomposition of the income inequality also indicates that the between-group components of the Theil indices are lower in Poland than in the UK, especially in 2014. In both years - 2005 and 2014 - the between-group 
part of the Theil index in Poland does not exceed 10\%. In the whole period of 2005-2014, the between-group variability decreased in Poland, while it increased in the UK.

\section{References}

Bourguignon, F. (1979). Decomposable income inequality measures. Econometrica, 47, 901920.

Cowell, F.A. (1977). Measuring inequality. Oxford: Phillip Allan.

Cowell, F.A. (2006). Theil, Inequality Indices and Decomposition, Dynamics of Inequality and Poverty. Research on Economic Inequality, 13, 345-360.

Cowell, F.A., Kuga K. (1981). Additivity and the Entropy concept: An axiomatic approach to inequality measure. Journal Economic Theory, 25, 131-143.

Frosini, B.V. (2012). Approximation and decomposition of Gini, Pietra-Ricci and Theil inequality measures. Empirical Economics, 43 (1), 175-197.

Heshmati, A. (2004). A Review of Decomposition of Income Inequality. Discussion Paper No. 1221. Bonn: The Institute for the Study of Labor (IZA).

ILO (2015). Global Wage Report 2014/15: Wages and income inequality. Geneva.

Jansen, W., Dessens, J., Verhoeven, W.-J. (2013). Income Inequality Decomposition, Russia 1992-2002: Method and Application. Studies of Transition States and Societies, 5 (2).

Jenkins, S.P. (2009). Distributionally-Sensitive Inequality Indices and the GB2 Income Distribution. Review of Income and Wealth, 55 (2), 392-398.

Kim, E., Jeong, Y.H. (2003). Decomposition of Regional Income Inequality in Korea. The Review of Regional Studies, 33 (3), 313-327.

Larraz, B. (2015). Decomposing the Gini Inequality Index. An Expanded Solution with Survey Data Applied to Analyze Gender Income Inequality. Sociological Methods and Research, $44,508-533$.

OECD (2015). In it together: Why less inequality benefits all, Paris.

Rani, U., Furrer, M. (2016). Decomposing income inequality into factor income components: Evidence from selected G20 countries, ILO Research Paper No. 15.

Rohde, N. (2008). Lorenz Curves and Generalised Entropy Inequality Measures. In: D. Chotikapanich (eds), Modeling Income Distributions and Lorenz Curves (pp. 271-283). Economic Studies in Equality, Social Exclusion and Well-Being, vol 5. New York, NY: Springer.

Shorrocks, A.F. (1980). The Class of Additively Decomposable Inequality Measures. Econometrica, 48 (3), 613-625. 
Shorrocks, A.F. (1982). Inequality Decomposition by Factor Components. Econometrica, 50 (1), 193-211.

Shorrocks, A.F. (1984). Inequality Decomposition by Population Subgroups. Econometrica, 52 (6), 1369-1385.

Theil, H. (1967). Economics and Information Theory. Amsterdam, North-Holland. 